Original Article

\title{
Motor performance of young soccer players based on their biological age
}

\author{
MIROSLAV HOLIENKA ${ }^{1}$, MATEJ BABIC ${ }^{1}$, LADISLAVA DOLEŽAJOVÁ ${ }^{2}$, PETER ŠELINGER ${ }^{3}$, EVA \\ MUSILOVÁ ${ }^{3}$ \\ ${ }^{1}$ Department of Sports Games, Faculty of Physical Education and Sports, Comenius University in Bratislava \\ SLOVAKIA \\ ${ }^{2}$ Department of Athletics, Faculty of Physical Education and Sports, Comenius University in Bratislava \\ SLOVAKIA \\ ${ }^{3}$ Department of Sports Kinanthropology, Faculty of Physical Education and Sports, Comenius University in \\ Bratislava SLOVAKIA
}

Published online: December 30, 2017

(Accepted for publication December 02, 2017

DOI:10.7752/jpes.2017.04282

\begin{abstract}
:
The main purpose of our article was to broaden the knowledge of the level of the motor performance of young soccer players in puberty, taking into account their biological age. The object of our research was 18 soccer players in the U 15 category of the soccer club ŠK Slovan Bratislava divided into a subset with accelerated development $(\mathrm{n}=10)$ and a subset with retarded development $(\mathrm{n}=8)$. To assess the motor performance, a set of 3 tests to evaluate speed and speed-coordination (agility) capabilities was applied. The set of tests contained a $10 \mathrm{~m}$ run $(\mathrm{n}=10$ - average value of $1.61 \mathrm{~s}, \mathrm{n}=8$ - average value of $1.62 \mathrm{~s})$, a $30 \mathrm{~m}$ run $(\mathrm{n}=10$ average value of $4.13 \mathrm{~s}, \mathrm{n}=8$ - average value of $4.16 \mathrm{~s})$ and a $5 \times 10 \mathrm{~m}$ run with a change of direction $(\mathrm{n}=10-$ average value of $11.55 \mathrm{~s}, \mathrm{n}=8$ - average value of $11.70 \mathrm{~s}$ ). Using the Mann-Whitney $U$ test, we did not confirm in our case a statistically significant different level in the motor performance of the monitored sets with regard to the degree of their biological maturity.

Key words: soccer, young players, motor performance, biological age.
\end{abstract}

\section{Introduction}

In many research papers and in practice itself, the motor performance of the school population as well as of youth doing sports is assessed particularly by the calendar (chronological) age. However, it is generally known that biological growing up of youth is characterized by individual differences, which the level of the motor performance depends on (Havlíček, Šelingerová and Ramacsay 1989, Gaetano 2016).

The motor performance in puberty is significantly determined by the level of somatic development, and therefore the acceleration or retardation of the development is often the cause of different sports performance of children and youth of the same chronological age (Šelingerová, Havlíček and Moravec 1995).

The chronological age has a limited use as an indicator of the individual status (Beunen and Malina 1996). In sports practice it is therefore replaced by the biological (functional, real) age. The biological age is the most important indicator in detecting the interindividual variability of motor (motoric) performance of children and youth doing sports, especially during pre-puberty and puberty. According to Dobisíková (1999), the biological age can be defined as the summary of the wear and tear of the physiological, chemical and psychological functions of the organism. It is influenced by genetic factors, nutrition, social (living) conditions, diseases, and in our case, also probably by load during trainings and matches. The biological age cannot be measured by the number of years (months, days) that have elapsed since birth as in the case of chronological age. Therefore, their numerical value may not always match. The biological age thus differs from the chronological age in most people. Developmental acceleration or developmental retardation may occur. The most significant differences between the chronological and biological ages due to the intensity of biological changes occur between 10 and 16 years of life (Reiter and Lee 2002). The biological age is not only interesting for pediatricians or parents, but also for coaches. In growing pubertal children, knowledge about the biological age is important for assessing and predicting their possible future physical growth (height), as well as the load that can be put on them in the training process. They enable to predict the period of the fastest development, the period when the physical growth ends as well as the period of optimal disposition for the best personal sporting performance.

Our paper aims to broaden the current knowledge about the level of the motor performance of young soccer players in the puberty stage, taking into account their biological age. By studying young (15-year-old) talented soccer players, we want to supplement the spectrum of knowledge from individual sports, which has been acquired to date by Šelingerová (1992), Šelingerová and Havlíček (1992), Šelingerová, Havlíček and 


\section{MIROSLAV HOLIENKA, MATEJ BABIC, LADISLAVA DOLEŽAJOVÁ, PETER ŠELINGER, EVA MUSILOVÁ}

Moravec (1995), Šelingerová and Šelinger (2004, 2005, 2009) as well as Zapletalová (1990), Doležajová (2002), Demcenco (2017) and Gomez-Lopez et al. (2017) through their active research activities in sports.

\section{Material and method}

Monitoring relationships between the chronological and biological ages in puberty is one of the most interesting issues in the process of growing and maturing of young athletes. Various available, various invasive and various accurate methods for determining the biological age are used in researches. From the methodological point of view the most accurate way (procedure) for determining the biological age is the bone age (Šelingerová, Šelinger 2005). The world-wide accepted method for determining the bone age is the TW3 method (Tanner et al., 2001). This method uses a radiographic image of wrist bones and fingers on the left hand (non-dominant) to determine the degree of their ossification (scoring-system). This method has a significant role in choosing children talented in sports, especially in the pre-puberty and puberty stages (age 10-15 years).

According to Šelingerová and Šelinger (2005) it enables to:

- identify the developmental position the individual is in compared to their chronological age at the time of the measurement (the individual is in limits, they are accelerated, or retarded),

- determine the rate of growth,

- predict adult body height.

Although the process of maturation and growth is generally independent of the physical activity, the degree of biological maturity determines the motor performance (Šelingerová and Havlíček 1992). This means that children of the same chronological age but of different biological ages show or may show different motor performance in fitness tests (Šelingerová and Šelinger 2005). Based on the above, we assume that the level of the motor performance of young soccer players will depend on their biological maturity expressed in the bone age. In the group of developmentally accelerated soccer players, we expect from the statistical point of view a significantly higher level of the motor performance in speed and speed-coordination manifestations than in the group of developmentally retarded soccer players.

From the above hypothesis, the following tasks have emerged for our research:

1. identify the level of the motor performance of soccer players through special motor performance tests applicable for testing in divisions of youth talented in soccer using photocells,

2. identify the bone age of soccer players based on X-ray imaging via the TW3 method,

3. identify the correlation dependence between the bone age and selected special motor performance tests.

The subject of our research project was young soccer players in the U 15 category in ŠK Slovan Bratislava soccer club, who played in 2015/2016 competition year in the first league of older pupils. The biological age allowed to divide the set into a developmentally accelerated subset (As- $\mathrm{n}=10)$ and a developmentally retarded subset (Rs- $n=8)$. The mean value of the acceleration stage As was +1.07 years, the mean value of the retardation stage Rs was -0.55 years. The studied set was made up of boys who were born in 2001.

\section{Results}

To find out the motor performance level of 15-year-old soccer players, a set of three tests for speed and speed-coordination capabilities was used - a $10 \mathrm{~m}$ run, a $30 \mathrm{~m}$ run, and a 5 x $10 \mathrm{~m}$ run with a change of direction.

Table 1 Values of monitored indicators of developmentally accelerated soccer players $n=10(+)$

\begin{tabular}{llllllll}
\hline & $10 \mathrm{~m}(\mathrm{~s})$ & $30 \mathrm{~m}(\mathrm{~s})$ & $5 \times 10 \mathrm{~m}(\mathrm{~s})$ & Bone age & Height $(\mathrm{cm})$ & Weight $(\mathrm{kg})$ & BMI \\
\hline B.R. & 1.49 & 3.84 & 11.19 & 16.4 & 173.0 & 58.0 & 19.38 \\
G.D. & 1.64 & 4.12 & 11.57 & 16.0 & 182.5 & 79.7 & 23.93 \\
H.T. & 1.65 & 4.14 & 11.40 & 16.5 & 172.0 & 59.8 & 20.21 \\
CH.B. & 1.70 & 4.49 & 12.51 & 14.7 & 182.1 & 72.1 & 21.74 \\
L.J. & 1.58 & 4.17 & 11.92 & 15.2 & 179.6 & 65.2 & 20.21 \\
N.F. & 1.63 & 4.14 & 11.20 & 16.2 & 182.0 & 72.7 & 21.95 \\
S.D. & 1.62 & 4.11 & 11.60 & 17.7 & 179.9 & 66.4 & 20.52 \\
T.D. & 1.61 & 4.23 & 11.50 & 15.3 & 177.0 & 63.0 & 20.11 \\
U.M. & 1.65 & 4.18 & 11.42 & 15.4 & 166.4 & 52.6 & 18.99 \\
V.R. & 1.53 & 3.89 & 11.23 & 16.1 & 179.3 & 68.5 & 21.31 \\
Min & 1.49 & 3.84 & 11.19 & 14.7 & 166.4 & 52.6 & 18.99 \\
Max & 1.70 & 4.49 & 12.51 & 17.7 & 182.5 & 79.7 & 23.93 \\
Vr & 0.21 & 0.65 & 1.32 & 3 & 16.1 & 27.1 & 4.94 \\
Average & 1.61 & 4.13 & 11.55 & 15.95 & 177.4 & 65.8 & 20.84 \\
\hline
\end{tabular}

The group of developmentally accelerated soccer players achieved an average of $1.61 \mathrm{~s}$ in the $10 \mathrm{~m}$ run. The lowest measured value was $1.49 \mathrm{~s}$ and the highest measured value was $1.70 \mathrm{~s}$.

In the $30 \mathrm{~m}$ run, the average value was $4.13 \mathrm{~s}$. The lowest measured value was $3.84 \mathrm{~s}$ and the highest was $4.49 \mathrm{~s}$. The extent of variation in this test was $0.65 \mathrm{~s}$. 
In the $5 \times 10$ m run with a change of direction we recorded an average value of $11.55 \mathrm{~s}$. The lowest measured value was $11.19 \mathrm{~s}$ and the highest measured value was $12.51 \mathrm{~s}$. The extent of variation for this test was $1.32 \mathrm{~s}$.

The average body height was $177.4 \mathrm{~cm}$ when as many as three players reached a height of $182-182.5$ $\mathrm{cm}$. The height of the lowest player in this group was $166.5 \mathrm{~cm}$.

Table 2 Values of monitored indicators of developmentally retarded soccer players $n=8(-)$

\begin{tabular}{|c|c|c|c|c|c|c|c|}
\hline & $10 \mathrm{~m}(\mathrm{~s})$ & $30 \mathrm{~m}(\mathrm{~s})$ & $5 \times 10 \mathrm{~m}(\mathrm{~s})$ & Bone age & Height $(\mathrm{cm})$ & Weight (kg) & BMI \\
\hline Č.K. & 1.68 & 4.16 & 11.43 & 13.7 & 172.7 & 59.5 & 19.95 \\
\hline H.M. & 1.57 & 4.02 & 12.90 & 14.6 & 173.9 & 66.7 & 22.06 \\
\hline K.A. & 1.53 & 3.97 & 11.60 & 14.9 & 184.8 & 79.3 & 23.22 \\
\hline L.S. & 1.60 & 4.33 & 11.44 & 14.0 & 163.1 & 53.9 & 20.26 \\
\hline M.M. & 1.65 & 4.33 & 11.79 & 14.9 & 164.3 & 61.8 & 22.89 \\
\hline P.P. & 1.60 & 3.96 & 11.49 & 14.5 & 177.3 & 71.2 & 22.65 \\
\hline N.L. & 1.71 & 4.24 & 11.68 & 14.2 & 162.7 & 56.7 & 21.42 \\
\hline T.A. & 1.62 & 4.25 & 11.30 & 14.5 & 169.0 & 62.0 & 21.71 \\
\hline Min & 1.53 & 3.96 & 11.30 & 13.7 & 162.7 & 53.9 & 19.95 \\
\hline Max & 1.71 & 4.33 & 12.90 & 14.9 & 184.8 & 79.3 & 23.22 \\
\hline $\mathrm{Vr}$ & 0.18 & 0.37 & 1.60 & 1.2 & 22.1 & 25.4 & 3.27 \\
\hline Average & 1.62 & 4.16 & 11.70 & 14.41 & 170.9 & 63.9 & 21.77 \\
\hline
\end{tabular}

The group of developmentally retarded soccer players achieved an average of $1.62 \mathrm{~s}$ in the $10 \mathrm{~m}$ run. The lowest measured value was $1.53 \mathrm{~s}$ and the highest measured value was $1.71 \mathrm{~s}$.

In the $30 \mathrm{~m}$ run, the average value was $4.16 \mathrm{~s}$. The lowest measured value was $3.96 \mathrm{~s}$ and the highest was $4.33 \mathrm{~s}$. The extent of variation in this test was $0.37 \mathrm{~s}$.

In the $5 \times 10 \mathrm{~m}$ run with a change of direction we recorded an average value of $11.70 \mathrm{~s}$. The lowest measured value was $11.30 \mathrm{~s}$ and the highest measured value was $12.90 \mathrm{~s}$. The extent of variation for this test was $1.60 \mathrm{~s}$.

The average body height was $170.9 \mathrm{~cm}$ when one player reached a height exceeding $180 \mathrm{~cm}$, namely as many as $185 \mathrm{~cm}$. The height of the lowest player in this group was $162.5 \mathrm{~cm}$.

\section{Discussion \\ 10 m run}

$10 \mathbf{m}$

Result 1 - U-value

The $U$-valueis 39. Thecriticalvalueof $U$ at $p<.05$ is 17 . Therefore, theresultisnotsignificantat $p<.05$.

Result 2 - Z-ratio

TheZ-Scoreis -0.04443 . The $p$-valueis .9681. Theresultisnotsignificantat $p<.05$.

Result 3 - Cohen $r$

Cohen $r$ is- 0,01 .

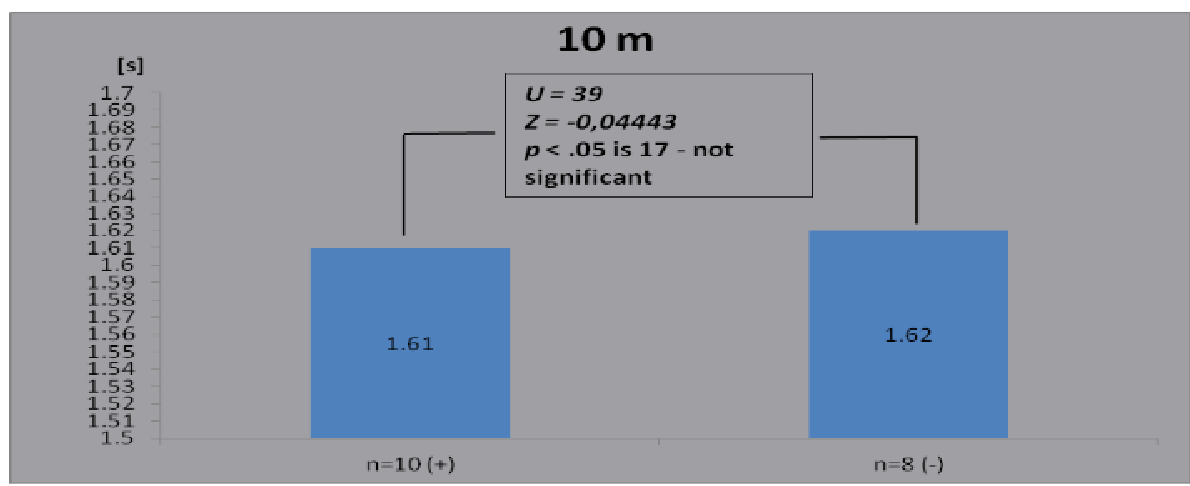

Fig. 1 Comparison of values reached in the $10 \mathrm{~m}$ run

In the $10 \mathrm{~m}$ run, the group of developmentally accelerated soccer players compared to the group of retarded soccer players achieved a better time by only 0.01 second. Therefore the value obtained is not statistically significant. Since it is the shortest running section, the measured difference value is more or less clear. Interestingly, however, the second highest player of the group of accelerated soccer players $(182.1 \mathrm{~cm})$ achieved the worst time $(1.70 \mathrm{~s})$ at this distance within the introductory group.

Equally interesting is the fact that the body height $(173 \mathrm{~cm})$ of the player with the best achieved time $(1.49 \mathrm{~s})$ is lower than the average body height in the group of developmentally accelerated soccer players (177.4 
$\mathrm{cm})$ in this subset. The second best time for this distance $(1.53$ seconds) was reached by the player with the highest body height $-185 \mathrm{~cm}$. Research results therefore show that for the monitored set in the $10 \mathrm{~m}$ run, neither the biological age nor the body height were the main factor in achieving the motor performance.

\section{$30 \mathrm{~m}$ run}

$30 \mathrm{~m}$

Result 1 - U-value

The $U$-valueis 32. Thecriticalvalueof $U$ at $p<.05$ is 17 . Therefore, theresultisnotsignificantat $p<.05$.

Result 2 - Z-ratio

TheZ-Scoreis -0.66639 . The $p$-valueis .50286. Theresultisnotsignificantat $p<.05$.

Result 3 - Cohen $r$

Cohen $r$ is- 0,16 .

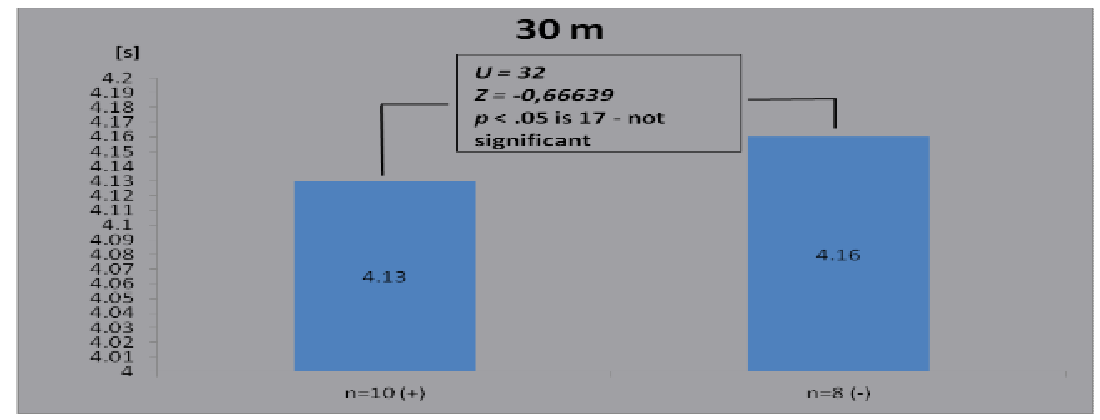

Fig. 2 Comparison of values reached in the $30 \mathrm{~m}$ run

In the $30 \mathrm{~m}$ run, the group of developmentally accelerated soccer players compared to the group of retarded soccer players achieved a better time by 0.03 second. Although the time difference increased compared to the $10 \mathrm{~m}$ run, the achieved value is not statistically significant again. This fact is a considerable surprise given the longer running section. Interestingly, in this case again, the second-highest player $(182.1 \mathrm{~cm})$ from all the observed soccer players, achieved the worst time of all probands -4.49 seconds.

Similarly as in the $10 \mathrm{~m}$ run, the fastest time in the $30 \mathrm{~m}$ run $(3.84 \mathrm{~s})$ was achieved again by the player with a height of $173 \mathrm{~cm}$ from the group of developmentally accelerated soccer players, who did not reach the average body height of this group. The player with the highest body height of $185 \mathrm{~cm}$ achieved the fourth fastest time - 3.97 seconds. Based on the results acquired in the $30 \mathrm{~m}$ run we can state likewise as in the $10 \mathrm{~m}$ run that the biological age and the body height in this test were not the main factors of the level of the motor performance.

\section{5 x 10 m run}

\section{$5 \times 10 m$}

Result 1 - U-value

The $U$-valueis 28.5. Thecriticalvalueof $U$ at $p<.05$ is 17 . Therefore, theresultisnotsignificantat $p<.05$.

Result 2 - Z-ratio

TheZ-Scoreis -0.97738 . The $p$-valueis .32708. Theresultisnotsignificantat $p<.05$.

Result 3 -Cohen $r$

Cohen $r$ is $-0,23$.

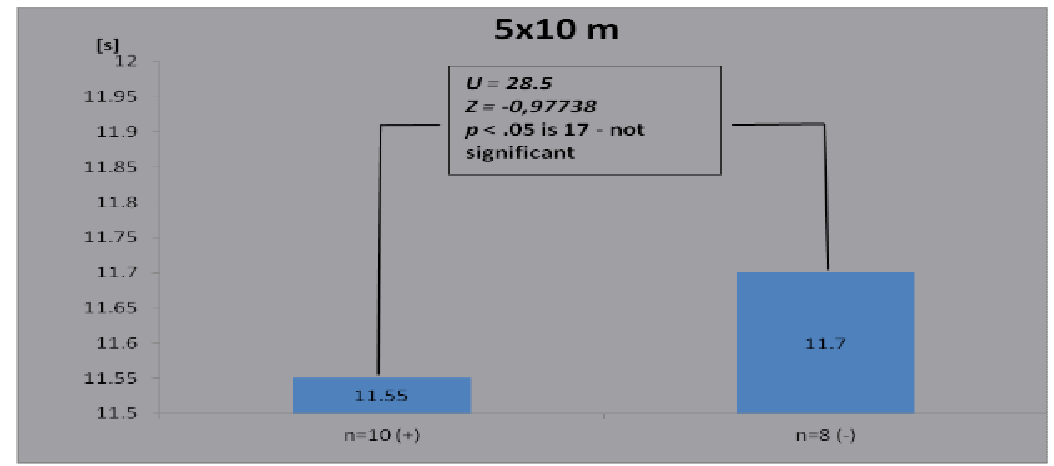

Fig. 3 Comparison of values reached in the $5 \times 10 \mathrm{~m}$ run

In the $5 \times 10$ m run with a change of direction, the group of developmentally accelerated soccer players had a better time compared to the group of retarded players. In this case, it is the most significant time difference 


\section{MIROSLAV HOLIENKA, MATEJ BABIC, LADISLAVA DOLEŽAJOVÁ, PETER ŠELINGER, EVA MUSILOVÁ}

of $0.15 \mathrm{~s}$ from all measured running sections. In this case, however, the value achieved is not statistically significant.

The fastest time, as in the $10 \mathrm{~m}$ and $30 \mathrm{~m}$ runs, was achieved by the player B.R. with a value of $11.19 \mathrm{~s}$ and a body height of $173 \mathrm{~cm}$. The player with the highest body height of $185 \mathrm{~cm}$ reached in this case the $15^{\text {th }}$ time in the order. The assumption concerning the positive impact of the biological age on the motor performance has not been confirmed in the set of young soccer players we monitored.

\section{Conclusions}

The level of the motor performance of youth both doing and non-doing sports in different age and performance categories is often studied and also often discussed by professionals. The biological age becomes one of the most important indicators in determining the inter-individual variability of motor performance in that period. Although statistical significance was not proved in any of the tests used, the results clearly show gradual increases in performance differences between the two groups of young soccer players $(0.01 \mathrm{~s} \rightarrow 0.03 \mathrm{~s} \rightarrow 0.15$ $\mathrm{s})$. The increasing extent of variation $(0.18 \mathrm{~s}$ to $1.60 \mathrm{~s})$ between the values obtained in the applied tests, although only minimally, points to different motor performance of the subsets. This diversity of 15-year-old soccer players' motor performance depending on the biological maturity was not confirmed in our research. We believe that, contrary to the quoted findings from research measurements of other authors, the non-confirmation of the results we expected occurred mainly due to the following reasons:

- lower quantity of the examined set divided into two subsets,

- considerable homogeneity of the examined set in terms of the training load,

- lower motivation of the probands because they completed their activities in the given age category.

\section{References}

Beunen, G. \& Malina, R. M. (1996). Growth and biological maturation. Relevance to athletic performance. In: The child and adolescent athlete. Oxford: Blackwell, 3- 24.

Demcenco, A. Development of applicative coordination abilities of 12-13 years old pupils through basketball elements. Journal of Physical Education and Sport, 17(2), 527-532.

Dobisíková, M. (1999). Určovaní věku. In: Stloukal, M. a kol. Antropologie. Praha: Národní muzeum.

Doležajová, L. a Koštial, J. (2002). Vzt’ah biologického veku a úrovne pohybových schopností 10-11-ročných žiačok ZŠ. In: Optimalizácia zat’aženia v telesnej a športovej výchove (pp. 36-42). Bratislava: STU.

Gaetano, A. (2016). Relationship between physical inactivity and effects on individual health status. Journal of Physical Education and Sport, 16(4), 1069-1074.

Gómez-López, M. (2017). Relative age effect during the selection of young handball player. Journal of Physical Education and Sport, 17(1), 418-423.

Havlíček, I., M. Šelingerová a Ramacsay, L. (1989). Závislost’ motorickej výkonnosti na biologickom veku. In: Teórie a Praxe tělesné Výchovy. 37(12), 757-761.

Reiter, E. O. \& Lee, P. E. (2002). Delayed puberty. In Adolescent Medicene. 13(1), 101-118.

Šelingerová, M. (1992). Stanovenie biologického veku a jeho uplatnenie v športe. Bratislava: Univerzita Komenského v Bratislave, Fakulta telesnej výchovy a športu, VÚTK.

Šelingerová, M. a Havlíček, I. (1992). Biologický vek - základné kritérium posudzovania pohybovej výkonnosti športovcov v puberte. In: Nové prístupy k skúmaniu v školskej telesnej výchove a športe (pp 106-110). Bratislava: Spoločnost' pre TV a Š.

Šelingerová, M., I. Havlíček a Moravec, R. (1995). Biologický vek športovcov v puberte, In: Acta facultatis. 36 (1), 99-104.

Šelingerová, M. a Šelinger, P. (2004). Metodika určovania biologického veku zo somatických údajov u populácie predpubertálneho a pubertálneho veku. Olomouc: UP

Šelingerová, M. a Šelinger, P. (2005). Význam určovania biologického veku v športe. In: Sledovanie rozvoja pohybových schopností a výkonnostného rastu športovo talentovaných detí a mládeže v závislosti od úrovne ich biologickej zrelosti (pp. 88-92) Bratislava: ICM Agency.

Šelingerová, M. a Šelinger, (2009). Vzt’ah medzi biologickým vekom a motorickou výkonnost’ou u mládeže v puberte. In: Výsledky somatických antropometrických výskumných merani v oblasti mládežníckeho športu (pp.97-103). Bratislava: FTVŠ UK.

Tanner, J. M. et al. (2001). Assessment of Skeletal Maturity and Prediction of Adult Height (TW3 Method). London: W.B. Saunders Press.

Zapletalová, L. (1990). Závislost’ pohybovej výkonnosti od telesného rozvoja. In: Telesný a funkčný rozvoj a pohybová výkonnost' 7-18 ročnej mládeže v ČSFR. Bratislava: MŠ SR. 